International Journal of Advancement in Life Sciences Research

Online ISSN: 2581-4877

journal homepage http://ijalsr.org

Original Article

\title{
Sagardighi Ash Pond: A New Water Bird Habitat in Murshidabad district, West Bengal, India.
}

\author{
Santi Ranjan Dey \\ Assistant Professor, Department of Zoology, Rammohan College, Kolkata, West Bengal, India \\ Correspondence E-mail : santiranjandey@rammohancollege.ac.in
}

\begin{abstract}
Flyash is a waste product generated from coal based thermal power plants. Dumping the ash in nearby wastelands is most preferred disposal method. Literature review has shown that despite the toxic nature of flyash, these ash ponds sites harbour significant avian diversity. Avifauna is an important indicator to evaluate different habitats both qualitatively and quantitatively. The Ash Pond of Sagardighi Thermal Power Station, Murshidabad is situated at $24^{\circ} 37^{\prime} 88^{\prime \prime} \mathrm{N}$ and $88^{\circ} 09^{\prime} 11^{\prime \prime} \mathrm{E}, 36 \mathrm{msl}$. It is a large water body of average $20 \mathrm{~m}$ deep. It is rain fed and also fed by water of Sagardighi Thermal Power Plant. This investigation was carried out during November, 2018 to March, 2020. Assessment of the avian diversity in the Sarardighi Ash pond in Murshidabad revealed that of the 42 species of aquatic birds found in this area, 16 are migratory species, 3 are local migrant and 23 species are residential in nature. The checklist of these birds, along with their IUCN status has been prepared. This paper provides an overview of status of wetland birds in Sagardighi Ash Pond, Murshidabad.
\end{abstract}

Keywords: Avifauna, waterbird, IUCN status, Sagardighi Ash Pond, Murshidabad.

\section{Introduction}

Wetlands are unique, productive ecosystems where terrestrial and aquatic habitats meet. Presence or absence of birds indicates ecological conditions of wetlands. It is the link between food web and nutrient cycle because most birds are able to quickly respond to any change in the habitat and climatic condition (Lee and Rotenberry, 2005, Reinkensmeyer et al., 2007).

Wetland is a complex natural system that harbors a wide variety of flora and fauna, all of great economic, aesthetic and scientific importance (Zedler and Kercher, 2005; Ramsar, 2007). Wetlands are a critical part of our natural environment. They protect our shores from wave action, reduce the impacts of floods, absorb pollutants and improve water quality. They provide habitat for animals and plants and many contain a wide diversity of life, supporting plants and animals. Wetlands provide numerous ecological goods and services but are under tremendous stress due to rapid urbanization, industrialization and agricultural intensification (De et al., 2018).

Wetland generally includes swamps, marshes, bogs and similar areas. India, with its varying topography and climatic regimes, supports diverse and unique wetland habitats (Prasad et al., 2002). Wetlands are common and an integral feature of the landscape of West Bengal. Wetlands are those areas inundated or saturated by surface or ground water at a frequency and duration sufficient to support and that under normal circumstances, 
do support a prevalence of vegetation typically adopted for life in saturated soil conditions. Wetlands are not wasteland at all they are valuable natural wonderlands that keep the environment in a balance state. But sadly these wetlands are treated as wasteland and waste is deposited there.

\section{Ash Ponds}

Flyash is a waste product generated from coal based thermal power plants. Dumping the ash in nearby wastelands is most preferred disposal method adopted by the agencies. In India, such depositions are often transformed in to varying sizes of ponds that are known as fly ash ponds. Ash pond is a common available disposal facility for thermal power plants. The pond ash is subjected to weathering and the ions present in ash migrate to the soil and subsequently to the ground water over a period of time. Studies have been conducted to assess the effect of pond ash on ground water quality (Suresh et al, 1998). It has been reported that Pond ash contributes to two major environmental problems: generation of respirable particulate matter (a major air pollutant) and pollution of soil and water due to leaching of heavy metals (Ghosh and Goel, 2014). It has been reported that despite the toxic nature of flyash, these ash ponds sites harbour significant avian diversity (Koparde et al, 2012).

\section{Avifauna}

The avian world has always been a fascination to the human world. Mythological documents hold a number of examples of birds being worshiped as goods with magical powers by the ancient civilizations. Even today winged wonders continue to be the subject of our astonishment primarily because of their ability to fly, their ability to build extraordinarily intricate nests, and of course, the brilliant colour of their plumage - features that no human being can replicate. Taxonomically birds are categorized in "Orders" "Families" and "Genera" and "species". But overall they are divided into two groups: Passeriformes (or Passerines) and Non Passeriformes (non passerines). At least $60 \%$ of all bird species are Passeriformes or song birds, their distinguishing characteristics being their specialized leg structure, vocal structure and brain-wiring which allows them to produce complex songs. The non-passerine comprises 28 out of 29 orders of birds in the world. Throughout the world approximately 11,000 species are found. India is having 1301 species. West Bengal has $57.69 \%$ of the total avian fauna (750 species).

\section{Identification of avifauna}

Birds are great indicators of our environment and watching birds and their behaviors helps us to understand our nature better. Avifauna are important for the ecosystem as they play various roles as scavenger, pollinators, seeds dispersal agent and predators of insect pest and an important indicator to evaluate different habitats both qualitatively and quantitatively. Identification of bird is generally based on combination of various characteristics. The bird anatomy includes the plumage colour, overall colour, head shape, beak shape, feet structure, the habitat character, season of occurrence, feeding behavior, flying behavior, display behavior and flaking are also important characters. Unfortunately global diversity of birds is decreasing due to anthropogenic activities and climate changes. IUCN Red List of endangered birds has already recognized 1226 bird species as threatened globally and India with 88 threatened bird species. There are many nomenclatures used by different research groups. In this investigation Manakadan and Pittie's Standardized common and scientific names of birds of Indian subcontinent was followed (Manakadan and Pittie, 2001).

According to Bird Life International (2001), the wetland of this area lies in Biome - 11 (IndoMalayan tropical dry zone). Thirteen big fresh water wetlands, out of 23 (>100 hectare) in West Bengal, are present in different blocks of the district Murshidabad. In Bengal the large or small, permanent or seasonally waterlogged marshes are popularly known as "beel". The wetlands of this region are generally palustrine (floodplains, seasonal waterlogged, marsh), lacustrine (Lakes) and riverine types. All these wetlands are directly or indirectly connected with the different rivers like Ganga, Babla, Jalangi, Bhairab etc.

Wetlands are one of the most threatened habitats of the world. Wetlands in India, as 
elsewhere are increasingly facing several anthropogenic pressures (Prasad et al., 2002). The rapidly expanding human population; large scale changes in land use/land cover; burgeoning development projects and improper use of watersheds have all caused a substantial decline of wetland resources of the country. Significant losses have resulted from its conversion threats from industrial, agricultural and various urban developments. These have led to hydrological perturbations, pollution and their effects. Unsustainable levels of grazing and fishing activities have also resulted in degradation of wetlands. The current loss rates in India can lead to serious consequences, where $74 \%$ of the human population is rural and many of these people are resource dependent.

Healthy wetlands are essential in India for sustainable food production and potable water availability for humans and livestock. They are also necessary for the continued existence of India's diverse populations of wildlife and plant species; a large number of endemic species are wetland dependent. Most problems pertaining to India's wetlands are related to human population. Many species of fishes, amphibians, reptiles, birds and mammals depend on the wetland habitat for breeding, foraging and for their shelter supported by the diverse plant species. One of the best known functions of wetlands is to provide habitat for birds which use wetlands for breeding, nesting and rearing of young ones, besides using them as a source of drinking water, for feeding, resting, shelter and social interaction.

\section{Importance of Wetland Birds:}

Wetland in India which provides a unique habitat to aquatic flora and fauna as well as numerous birds includes migratory species. Of the 310 species of wetland birds found in India (Kumar et al., 2005) almost half of these are migratory and visit India from cold areas of different part of China, Russia, central Asia, Tibet and from across the entire range of the Himalaya (Kumar and Gupta. 2009, 2013). Wetlands are complex and productive ecosystems (Maltby, E.R. 1986) that occupy about six percent of the Earth's land surface (Maltby and Turner. 1983). Wetlands are known as "biological supermarkets" because of the extensive food chains and rich biodiversity they support, providing unique habitats for a wide range of flora and fauna (Mitsch and Gosselink, 2000). Wetlands are important habitats for birds, which use them for feeding, roosting, nesting and rearing young (Weller, 1999). Water birds are an important component of almost of the wetland ecosystem as they occupy several trophic levels in the Food Web of wetland ecosystem (Stewart, 2001). Water birds are only the most prominent groups that attract public to wetlands, but also are good bio-indicators and useful models for studying a variety of environmental problems (Urfi et al, 2005).

Wetlands are facing tremendous anthropogenic pressure, which can greatly influence the population structure of the bird community. In the last century, over $50 \%$ of wetlands in the world have been lost, and the remaining wetlands have been degraded to different degrees because of the adverse anthropogenic activities (Stewart, 2001). The loss of wetland through human interferences has lead to a decline in several water bird populations in West Bengal (Maltby, 1986). There are numerous wetlands for birds across West Bengal, only in some water birds have been systematically surveyed and documented. The wetlands in Murshidabad district, West Bengal, have long been known to support rich diversity of water birds. The actual water bird population needs to be surveyed and documented.

\section{Background information of Birds of Murshidabad district:}

Murshidabad district contain 43 very large wetlands. Of these 30 wetlands are frequently used for organized fisheries. 13 wetlands are wild in nature till date. Literature review has revealed that data on water birds of Murshidabad is available for only 4 (four) wetlands of Murshidabad. These literatures are only describing avifauna of four wetlands viz.

1. Motijheel (De et al., 2016);

2. Ahiran (Chattoraj et al, 2016; Ambiya et al., 2015; Mistry and Mukherjee, 2015).

3. Patan (Dey, 2019)

4. Bisnupur Beel (Bhattacharya and Sarkar, 2017). 
Int J Adv Life Sci Res. Volume 3(4)26-36

Bhattacharya and Sarkar (2017) described a detailed account of flora and fauna of a fishery known as Bisnupur Beel, an Ox-Bow adjacent to Berhampore. Author has been working on the wetlands of Murshidabad which has resulted in some findings(Dey, 2019). A comparative account of the impact of the urban development on plant and wetland dependent bird population along the two arms of an ox-bow lake, Motijheel in Murshidabad district was investigated by author and co workers ((De et al., 2016). The vertebrate Biodiversity (including avifauna) in and around Ahiran: An important Wetland in Murshidabad, West Bengal, India was studied by author and co workers (Ambiya et al., 2015). However in these studies the bird count was not investigated. Bird photographs were also rare. So, there was an urgent need for actual bird census in Murshidabad district. The status of water birds in the Sagardighi Ash Pond has not been documented at all. The present study conducted an assessment to address the existing information gap.

\section{Murshidabad district}

Murshidabad is a district of West Bengal in eastern India (Fig. 1). Situated on the left bank of the river Ganges, the district is very fertile. Covering an area of $5,341 \mathrm{~km}^{2}$ (2,062 sq mi) and having a population $5.863 \mathrm{~m}$ (according to 2001 census) it is a densely populated district and the ninth most populous in India (out of 640). It borders Malda district to the north, Jharkhand's Sahebganj district and Pakur district to the north-west, Birbhum to the west, Bardhaman to the south-west and Nadia district due south. The international border with Bangladesh's Rajshahi division is on the east. The district comprises two distinct regions separated by the Bhagirathi River. To the west lies the Rarh, a high, undulating continuation of the Chota Nagpur plateau. The eastern portion, the Bagri, is a fertile, low-lying alluvial tract, part of the Ganges Delta. The district is drained by the Bhagirathi and Jalangi rivers and their tributaries (Fig. 2). Bhagirathi is a branch of the Ganges, and flows southwards from Farakka barrage where it originates from the Ganges. It flows southwards through the district and divides it into more or less equal halves.

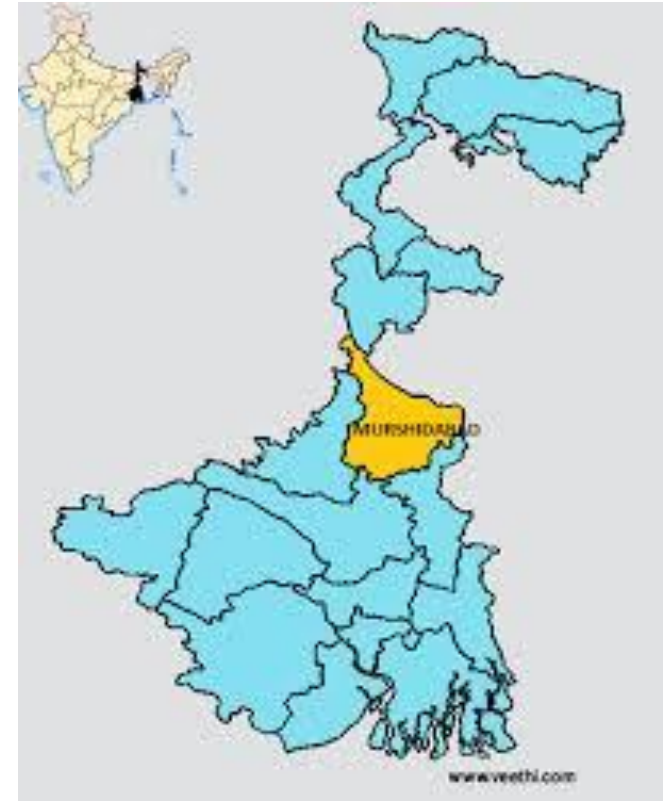

Fig. 1. Location Map of Murshidabad district in the state of West Bengal, India.

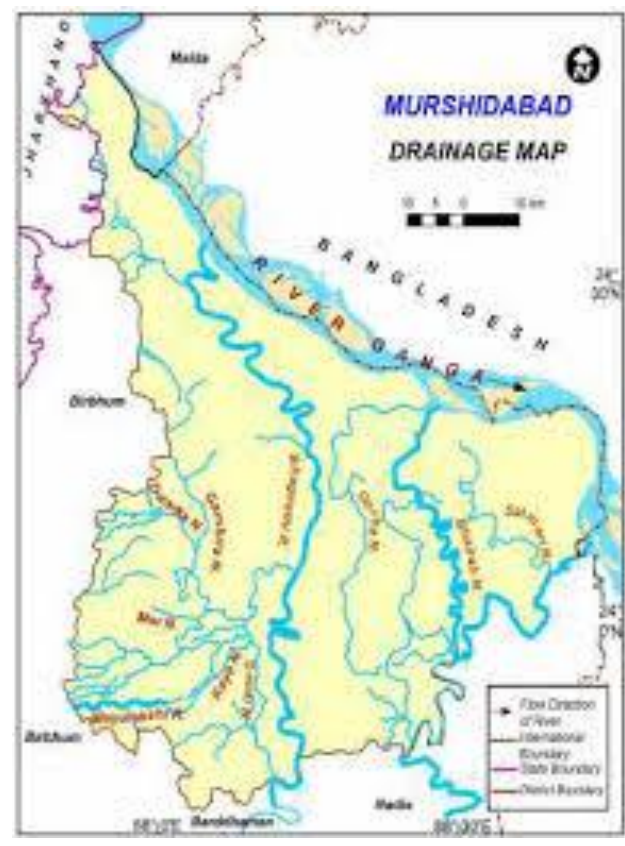

Fig. 2. Map of Murshidabad district with the main rivers

Study Area:

The Sagardighi Thermal Power Station is a 1,600-megawatt (MW) coal-fired power station in Murshidabad, West Bengal, India. The plant is located at Manigram Village, 13 kilometres north of Sagardighi town in Murshidabad District. The power plant is operated by the West Bengal Power Development Corporation Limited. The Ash Pond is located near the Thermal Power Plant. The project site is 
Int J Adv Life Sci Res. Volume 3(4)26-36

The approximate latitude and longitude of the project site are as follows:

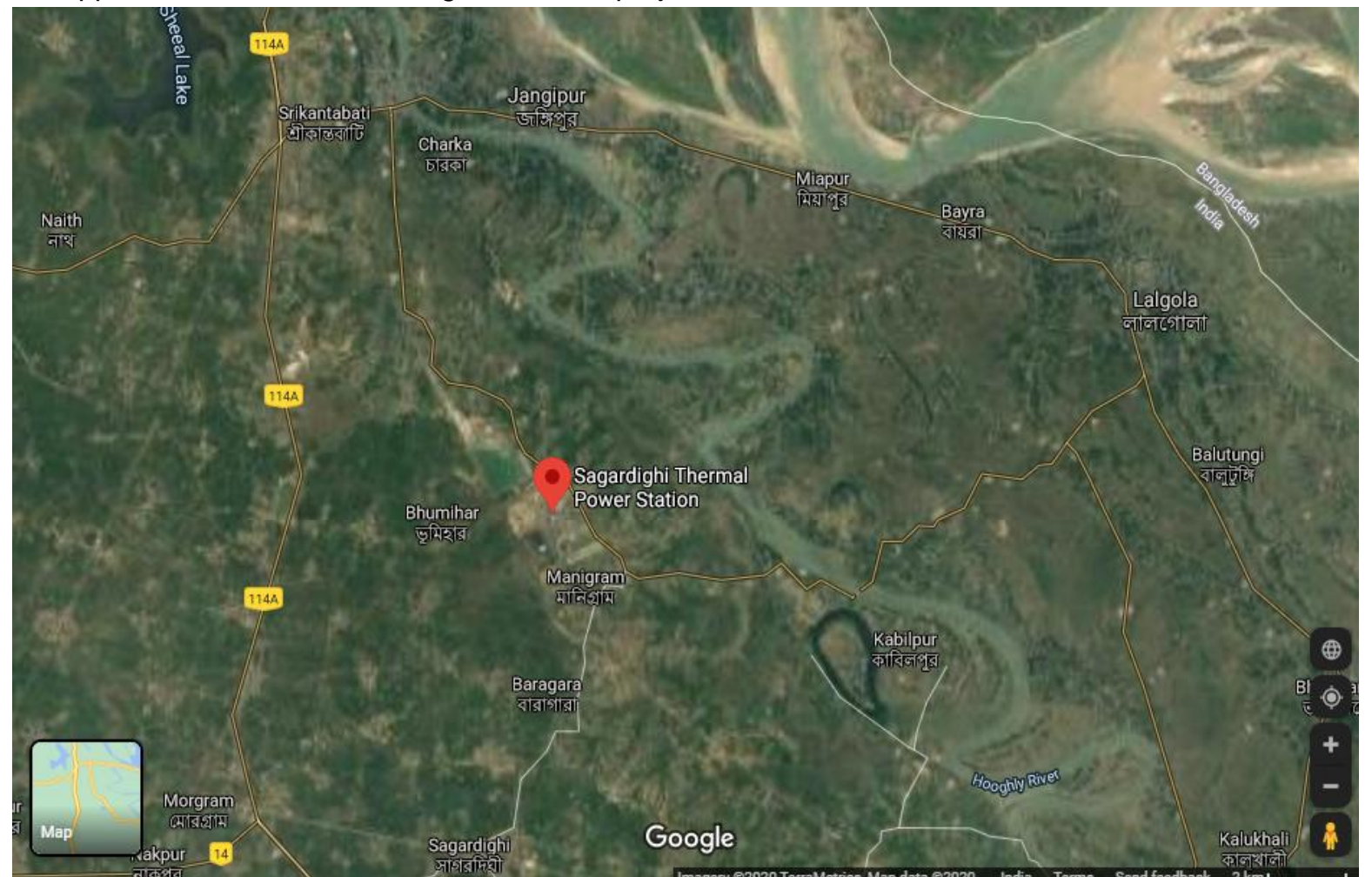

Fig. 3. Google Earth image of the Sagardighi Thermal Power Plant, Murshidabad.

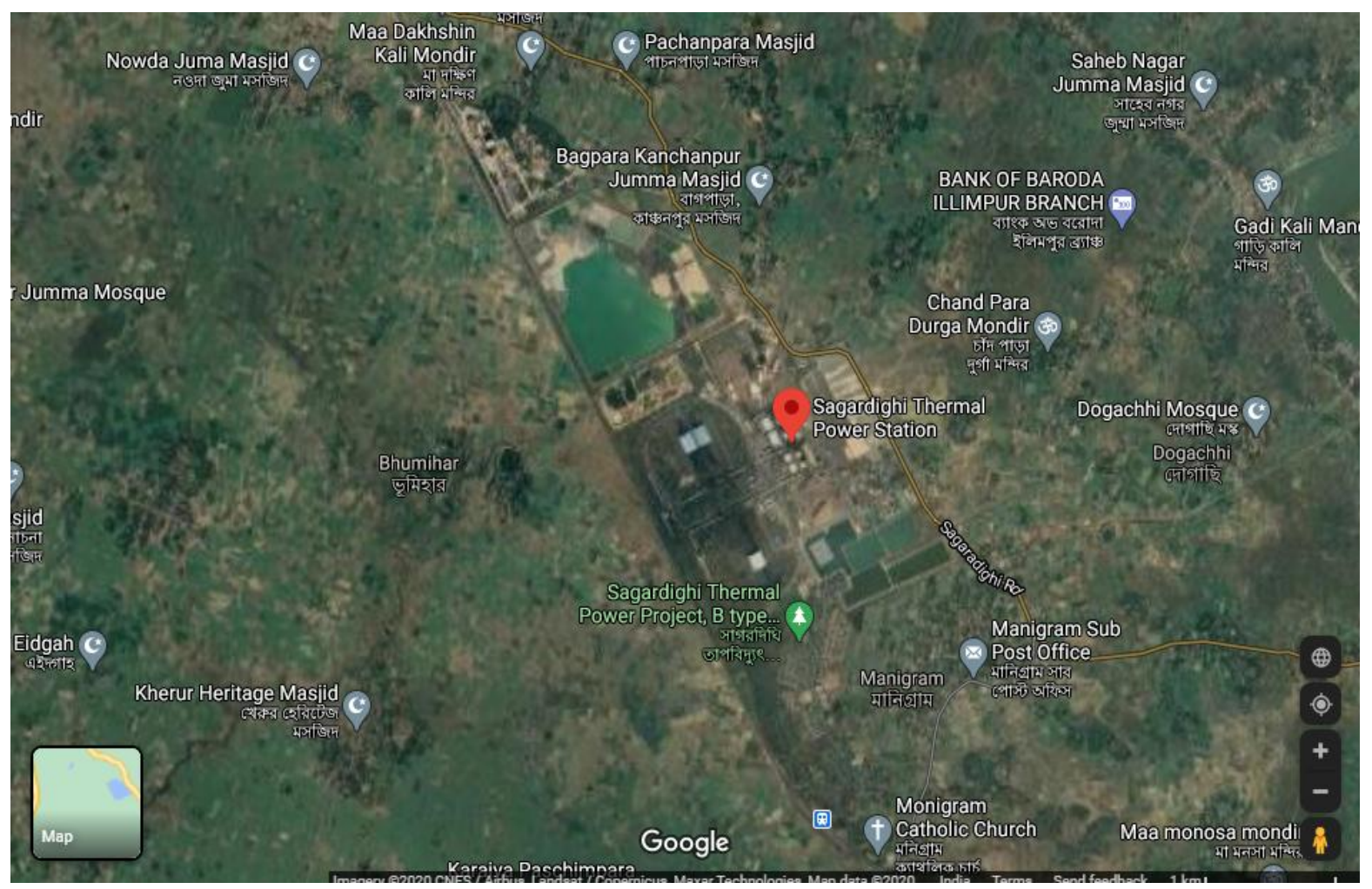

Fig. 4. Google Earth image of the Ash Pond of the Sagardighi Thermal Power Plant, Murshidabad. 
encompassed by villages Manigram, Chhamugram, Karaia, Thakurpara on the south; Bhumhar, Khasittor, Ekrakhi on the west; Dhalo, Bagpara, Santoshpur on the north and Harirampur, Chandparam, Dogachhi on the east. Bandel-Barharwa broad gauge line of Eastern Railway grazes past the western fringe of the plot. River Bhagirathi is within $5 \mathrm{~km}$ east of the project site. The unit generates fly ash. There is a high demand for fly ash from the cement plants nearby. Some of the fly ash from the station is lifted by various consumers. The balance ash is disposed into the existing Sagardighi Ash Pond near the Thermal Plant.

The Sagardighi Ash Pond is a large water body of average $20 \mathrm{~m}$ deep. It is rainfed and also fed by water of Sagardighi Thermal Power Plant.

Physiography of the study sites:

\begin{tabular}{|l|l|l|}
\hline & $\begin{array}{l}\text { Approximate } \\
\text { Latitude }\end{array}$ & $\begin{array}{l}\text { Approximate } \\
\text { longitude }\end{array}$ \\
\hline \multirow{3}{*}{$\begin{array}{l}\text { Sagardighi } \\
\text { Ash Pond }\end{array}$} & $24^{\circ} 22^{\prime} 06^{\prime \prime} \mathrm{N}$ & $88^{\circ} 05^{\prime} 05^{\prime \prime} \mathrm{E}$ \\
\cline { 2 - 3 } & $24^{\circ} 23^{\prime} 08^{\prime \prime} \mathrm{N}$ & $88^{\circ} 05^{\prime} 25^{\prime \prime} \mathrm{E}$ \\
\cline { 2 - 3 } & $24^{\circ} 22^{\prime} 38^{\prime \prime} \mathrm{N}$ & $88^{\circ} 06^{\prime} 05^{\prime \prime} \mathrm{E}$ \\
\cline { 2 - 3 } & $24^{\circ} 22^{\prime} 20^{\prime \prime} \mathrm{N}$ & $88^{\circ} 05^{\prime} 28^{\prime \prime} \mathrm{E}$ \\
\hline
\end{tabular}

\section{Material and Methods}

1. The birds were counted by the method described in Bird Census Technique (Bibby et al., 2000).

2. Birds were observed by using Olympus Binocular and photographs were taken by using SONY DSC HX $300 \mathrm{~V}$ and NIKON DSLR camera.

3. Birds were identified from photograph by using the book "Hand Book of Indian Wetland Birds and their Conservation" which is a Zoological Survey of India publication (Kumar et al, 2005).

4. For counting of birds, each wetland was divided into 8 hypothetical grids. In each grid birds were counted by two people using counter. The counting time of birds were morning $8 \mathrm{AM}$ to $10 \mathrm{AM}$.
5. Entire wetland was covered during counting.

6. Each site was visited for a minimum three times to maximum eight times. Different days around the same time. Birds were counted in a particular date, as and when migratory birds appear.

7. The period of Study was 2018 (November) to 2020 (March).

8. Manakadan and Pittie's Standardized common and scientific names of birds of Indian subcontinent was followed.

9. Species were classified as:

a. Resident (R): The bird species were classified as Resident when found in all suitable habitats throughout the year.

b. Migrant (M): When the bird species is found only during a particular season.

c. Local migrant (LM): When the bird taxa is resident in West Bengal but found in the study site during a particular season.

10. The identified bird species were categorized based on the IUCN (International Union for Conservation of Nature) Red List criteria to provide information on species conservation status and indicate the importance of conserving the study wetland habitats for bird conservation (IUCN 2017).

\section{Results and Discussion}

42 (Forty two) taxa of water birds have been identified from Sagardighi Ash Pond, Murshidabad. Of these 23 (Twenty three) taxa were resident $(R)$ water birds of Sagardighi Ash Pond. 3 taxa were local migrants. The rest 16 (Sixteen) taxa were migrant $(\mathrm{M})$ water birds of Sagardighi Ash Pond. The checklist with residential status as well as the IUCN status is given as Table 1. 
Table 1. Checklist of water birds of Sagardighi Ash Pond with IUCN status

\begin{tabular}{|c|c|c|c|}
\hline Family wise Species & Common name & $\begin{array}{l}\text { Residential status - } \\
\text { a) Migrant (M) } \\
\text { b) local migrant (LM) } \\
\text { c) Resident (R) }\end{array}$ & $\begin{array}{l}\text { Conservation } \\
\text { status } \\
\text { following } \\
\text { IUCN } 2015\end{array}$ \\
\hline \multicolumn{4}{|l|}{$\begin{array}{l}\text { ANSERIFORMES: } \\
\text { Anatidae }\end{array}$} \\
\hline Dendrocygna javanica (Horsfield, 1821) & $\begin{array}{l}\text { Lesser Whistling- } \\
\text { duck }\end{array}$ & $\mathrm{R}$ & LC \\
\hline Anser anser (Linnaeus, 1758) & Greylag Goose & $\mathrm{M}$ & LC \\
\hline Tadorna ferruginea (Pallas, 1764) & Ruddy Shelduck & $\mathrm{M}$ & LC \\
\hline $\begin{array}{l}\text { Nettapus coromandelianus (Gmelin, JF, } \\
\text { 1789) }\end{array}$ & $\begin{array}{l}\text { CottonPygmy- } \\
\text { goose }\end{array}$ & $\mathrm{M}$ & LC \\
\hline Netta rufina (Pallas, 1773) & $\begin{array}{l}\text { Red-crested } \\
\text { Pochard }\end{array}$ & $\mathrm{M}$ & LC \\
\hline Aythya nyroca (Güldenstädt, 1770) & Ferruginous Duck & $\mathrm{M}$ & NT \\
\hline Aythya fuligula (Linnaeus, 1758) & Tufted Duck & $\mathrm{M}$ & LC \\
\hline Mareca strepera strepera (Linnaeus, 1758) & Gadwall & M & LC \\
\hline $\begin{array}{l}\text { Anas platyrhynchos platyrhynchos } \\
\text { Linnaeus, } 1758\end{array}$ & Mallard & $\mathrm{M}$ & LC \\
\hline Anas acuta Linnaeus, 1758 & Northern Pintail & $\mathrm{M}$ & LC \\
\hline \multicolumn{4}{|l|}{$\begin{array}{l}\text { PODICIPEDIFORMES: } \\
\text { Podicipedidae }\end{array}$} \\
\hline Tachybaptus ruficollis (Pallas, 1764) & Little Grebe & $\mathrm{R}$ & LC \\
\hline Podiceps cristatus (Linnaeus, 1758) & $\begin{array}{l}\text { Great } \quad \text { Crested } \\
\text { Grebe }\end{array}$ & M & LC \\
\hline $\begin{array}{l}\text { Podiceps [nigricollis or andinus] (= Podiceps } \\
\text { nigricollis) Brehm, CL, } 1831\end{array}$ & $\begin{array}{l}\text { Black-necked } \\
\text { Grebe }\end{array}$ & M & LC \\
\hline \multicolumn{4}{|l|}{$\begin{array}{l}\text { GRUIFORMES: } \\
\text { Rallidae }\end{array}$} \\
\hline $\begin{array}{l}\text { Amaurornis [phoenicurus or } \\
\text { olivacea] (= Amaurornis phoenicurus) } \\
\text { (Pennant, 1769) }\end{array}$ & $\begin{array}{l}\text { White-breasted } \\
\text { Water hen }\end{array}$ & $\mathrm{R}$ & LC \\
\hline Porphyrio porphyrio (Linnaeus, 1758) & $\begin{array}{ll}\text { Purple } & \text { Swamp } \\
\text { hen } & \end{array}$ & $\mathrm{R}$ & LC \\
\hline $\begin{array}{l}\text { Gallinula [chloropus or galeata] (= Gallinula } \\
\text { chloropus) (Linnaeus, 1758) }\end{array}$ & Common Moorhen & $\mathrm{R}$ & LC \\
\hline Fulica atra Linnaeus, 1758 & Common Coot & $\mathrm{M}$ & LC \\
\hline \multicolumn{4}{|l|}{$\begin{array}{l}\text { CICONIIFORMES: } \\
\text { Ciconiidae }\end{array}$} \\
\hline Anastomus oscitans (Boddaert, 1783) & Asian Openbill & $\mathrm{R}$ & LC \\
\hline $\begin{array}{l}\text { Ciconia episcopus [episcopus or } \\
\text { neglecta] (= Ciconia episcopus episcopus) } \\
\text { (Boddaert, 1783) }\end{array}$ & Asian Woollyneck & $\mathrm{R}$ & $\mathrm{VU}$ \\
\hline \multicolumn{4}{|l|}{$\begin{array}{l}\text { PELECANIFORMES: } \\
\text { Ardeidae }\end{array}$} \\
\hline Ixobrychus sinensis (Gmelin, JF, 1789) & Yellow Bittern & $\mathrm{R}$ & LC \\
\hline Nycticorax nycticorax (Linnaeus, 1758) & $\begin{array}{l}\text { Black-crowned } \\
\text { Night-heron }\end{array}$ & $\mathrm{R}$ & LC \\
\hline Ardeola grayii (Sykes, 1832) & Indian Pond-heron & $\mathrm{R}$ & LC \\
\hline $\begin{array}{l}\text { Bubulcus [ibis or coromandus] (= Bubulcus } \\
\text { ibis) (Linnaeus, 1758) }\end{array}$ & Cattle Egret & $\mathrm{R}$ & LC \\
\hline Ardea cinerea cinerea Linnaeus, 1758 & Grey Heron & $\mathrm{R}$ & LC \\
\hline $\begin{array}{l}\text { Ardea purpurea [purpurea or } \\
\text { bournei] (= Ardea purpurea purpurea) } \\
\text { Linnaeus, } 1766\end{array}$ & Purple Heron & $\mathrm{R}$ & LC \\
\hline Egretta garzetta (Linnaeus, 1766) & Little Egret & $\mathrm{R}$ & LC \\
\hline \multicolumn{4}{|l|}{$\begin{array}{l}\text { SULIFORMES: } \\
\text { Phalacrocoracidae }\end{array}$} \\
\hline Microcarbo niger (Vieillot, 1817) & Little Cormorant & $\mathrm{R}$ & LC \\
\hline \multicolumn{4}{|l|}{$\begin{array}{l}\text { CHARADRIIFORMES: } \\
\text { Charadriidae }\end{array}$} \\
\hline Charadrius dubius dubius Scopoli, 1786 & $\begin{array}{l}\text { Little } \\
\text { Plover }\end{array}$ & $\mathrm{M}$ & LC \\
\hline
\end{tabular}


Int J Adv Life Sci Res. Volume 3(4)26-36

\begin{tabular}{|c|c|c|c|}
\hline Vanellus indicus (Boddaert, 1783) & $\begin{array}{l}\text { Red-wattled } \\
\text { Lapwing }\end{array}$ & $\mathrm{M}$ & LC \\
\hline \multicolumn{4}{|l|}{$\begin{array}{l}\text { CHARADRIIFORMES: } \\
\text { Jacanidae }\end{array}$} \\
\hline Hydrophasianus chirurgus (Scopoli, 1786) & $\begin{array}{l}\text { Pheasant-tailed } \\
\text { Jacana }\end{array}$ & $\mathrm{R}$ & LC \\
\hline Metopidius indicus (Latham, 1790) & $\begin{array}{l}\text { Bronze-winged } \\
\text { Jacana }\end{array}$ & $\mathrm{R}$ & LC \\
\hline \multicolumn{4}{|l|}{$\begin{array}{l}\text { CHARADRIIFORMES: } \\
\text { Scolopacidae }\end{array}$} \\
\hline $\begin{array}{l}\text { Tringa nebularia nebularia (Gunnerus, } \\
\text { 1767) }\end{array}$ & $\begin{array}{l}\text { Common } \\
\text { Greenshank }\end{array}$ & LM & LC \\
\hline \multicolumn{4}{|l|}{$\begin{array}{l}\text { CHARADRIIFORMES: } \\
\text { Glareolidae }\end{array}$} \\
\hline Glareola lactea Temminck, 1820 & Little Pratincole & $\mathrm{M}$ & LC \\
\hline \multicolumn{4}{|l|}{$\begin{array}{l}\text { CHARADRIIFORMES: } \\
\text { Laridae }\end{array}$} \\
\hline $\begin{array}{l}\text { Chroicocephalus ridibundus (Linnaeus, } \\
\text { 1766) }\end{array}$ & Black-headed Gull & $\mathrm{M}$ & LC \\
\hline \multicolumn{4}{|l|}{$\begin{array}{l}\text { ACCIPITRIFORMES: } \\
\text { Pandionidae }\end{array}$} \\
\hline $\begin{array}{l}\text { Pandion [haliaetus or cristatus] (= Pandion } \\
\text { haliaetus) (Linnaeus, 1758) }\end{array}$ & Osprey & LM & LC \\
\hline \multicolumn{4}{|l|}{$\begin{array}{l}\text { ACCIPITRIFORMES: } \\
\text { Accipitridae }\end{array}$} \\
\hline Circus spilonotus Kaup, 1847 & $\begin{array}{l}\text { Western Marsh- } \\
\text { harrier }\end{array}$ & LM & LC \\
\hline Haliastur indus (Boddaert, 1783) & Brahminy Kite & $\mathrm{R}$ & LC \\
\hline $\begin{array}{l}\text { Milvus [migrans or aegyptius] (= Milvus } \\
\text { migrans) (Boddaert, 1783) }\end{array}$ & Black Kite & $\mathrm{R}$ & LC \\
\hline \multicolumn{4}{|l|}{$\begin{array}{l}\text { CORACIIFORMES: } \\
\text { Alcedinidae }\end{array}$} \\
\hline Alcedo atthis (Linnaeus, 1758) & $\begin{array}{l}\text { Common } \\
\text { Kingfisher }\end{array}$ & $\mathrm{R}$ & LC \\
\hline Ceryle rudis (Linnaeus, 1758) & Pied Kingfisher & $\mathrm{R}$ & LC \\
\hline Pelargopsis capensis (Linnaeus, 1766) & $\begin{array}{l}\text { Stork-billed } \\
\text { Kingfisher }\end{array}$ & $\mathrm{R}$ & LC \\
\hline Halcyon smyrnensis (Linnaeus, 1758) & $\begin{array}{l}\text { White-breasted } \\
\text { Kingfisher }\end{array}$ & $\mathrm{R}$ & LC \\
\hline
\end{tabular}

IUCN Status: LC: Least Concern, NT: Near Threatened, VU: Vulnerable

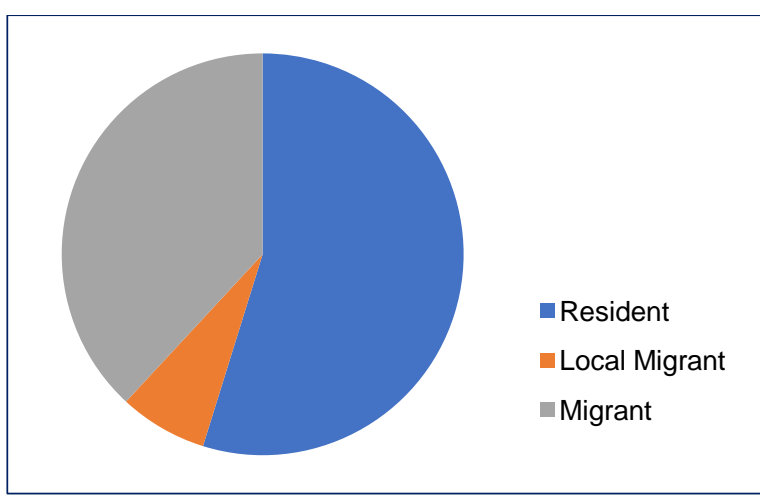

Fig. 5. Distribution of water birds of Sagardighi Ash Pond

\section{Discussion}

Literature review has revealed that Fly ash ponds associated with Nashik Thermal Power Station harboured significant avian diversity of 128 species (Koparde et al, 2012). Fly Ash can be used by plants as a source of nutrient (Jala and Goyal, 2006).

In this investigation it was found that $38.1 \%$ of the avifauna was migrant birds and $7.1 \%$ were local migrant birds. Around $54.8 \%$ of the total avifauna was resident birds (Table 2 ). It would be interesting to study changes in the migrant population in the future, The IUCN status of these migrant birds would be an interesting area of study. In this study the Migrant (M) Ferruginous Duck, Aythya nyroca (Güldenstädt, 1770) was found to be Near Threatened (NT). Another migrant the Asian Woollyneck, Ciconia episcopus [episcopus or neglecta] (= Ciconia episcopus episcopus) (Boddaert, 1783) was found to Vulnerable (VU). The rest 40 water birds were found to have the Least Concern (LC) status 
Int J Adv Life Sci Res. Volume 3(4)26-36

of IUCN. Some photographs of the birds are given in Fig 6-13.

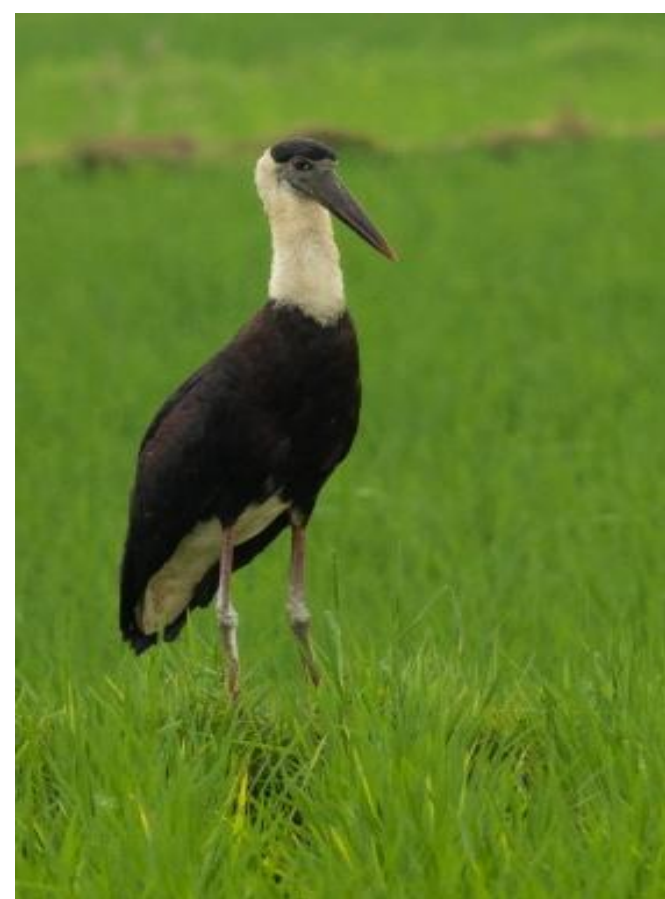

Fig. 6 Wooly Necked Stork

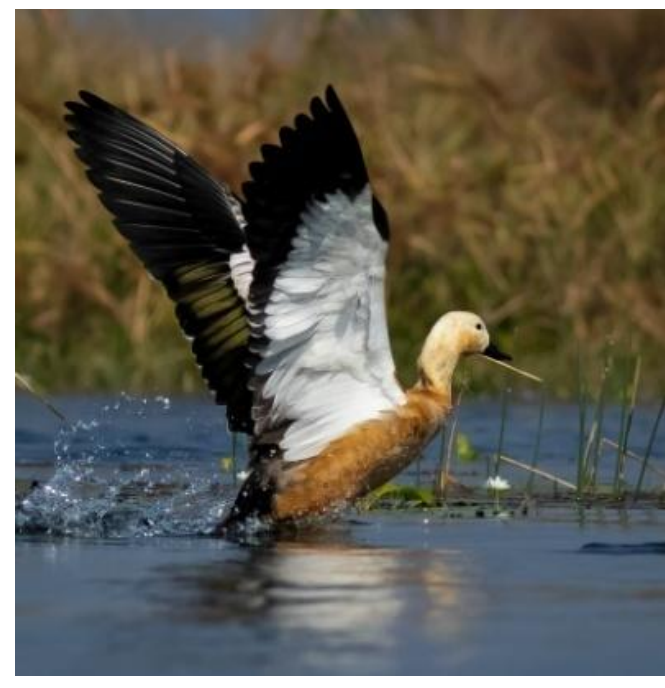

Fig. 7. Rudy Shell Duck

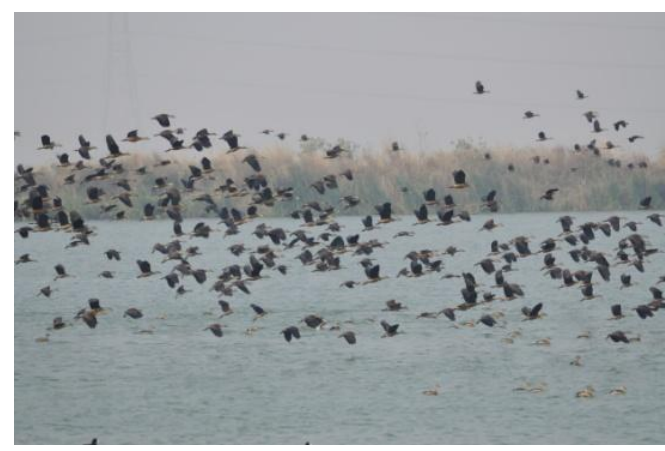

Fig. 8. Lesser Whistling Duck

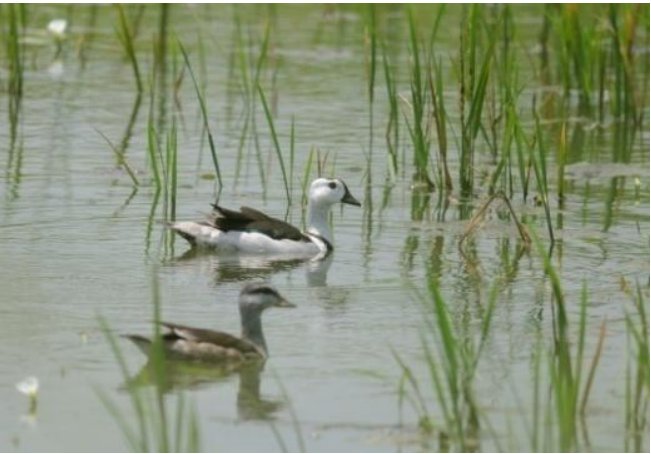

Fig. 9. Cotton Pygmy Goose

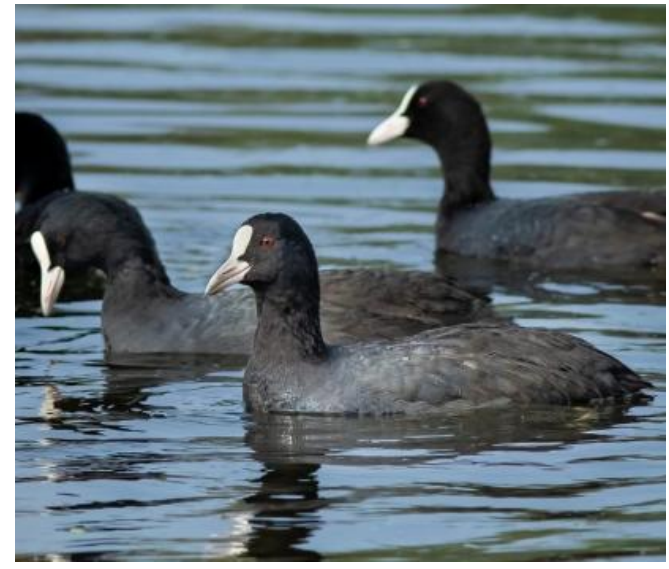

Fig. 10. Eurasian Coot

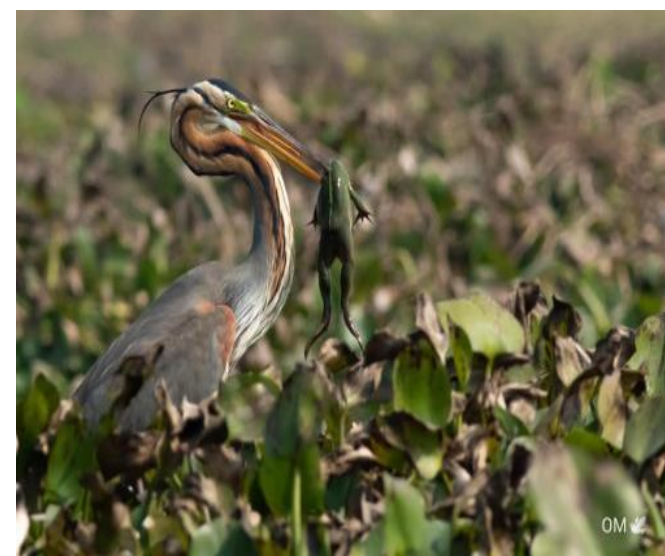

Fig. 11. Purple Heron

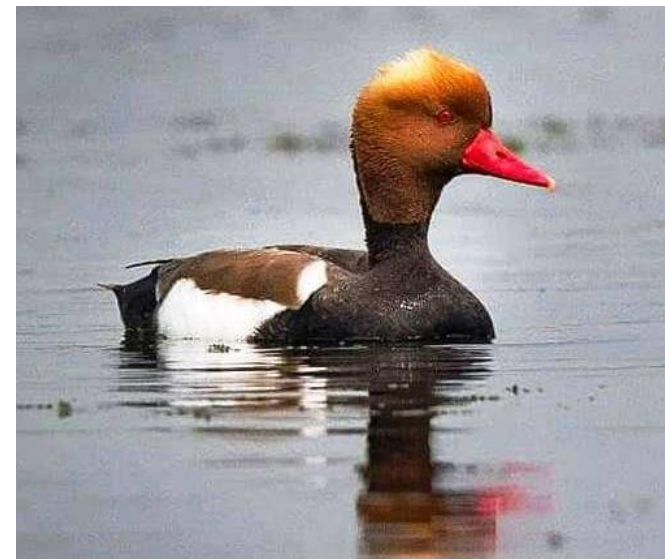

Fig. 12. Red Crested Poachard 
Int J Adv Life Sci Res. Volume 3(4)26-36

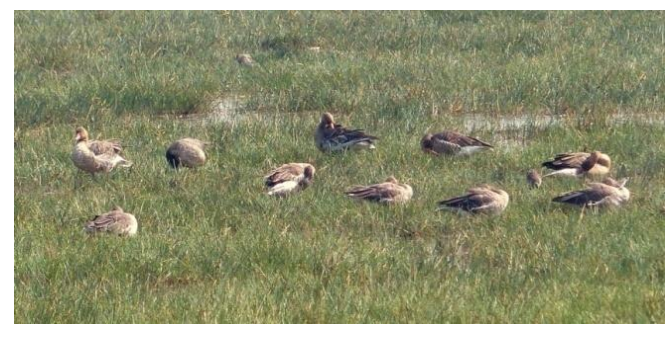

Fig. 13. Grey Leg Goose

\section{Conclusion:}

Among these 42 species 16 are migratory species, 3 are local migrant and 23 species are residential in nature. Sagardighi Ash Pond appears to be a new Water Bird Habitat in Murshidabad district. More studies need to be undertaken in future to find any association of the toxic nature of fly ash in the ash pond and avian diversity. It would be interesting to note if the number of migrant birds increase over the

\section{References}

Bibby CJ, Burgess ND, Hill DA, Mustoe S. 2000. Bird census techniques. Second edition. Academic Press; London. pp. 104-105.

Bird Life International, 2003. Saving Asia's Threatened Birds: A Guide for Government and Civil Society. BirdLife International, Cambridge, 246pp.

Bhattacharya, B. and Sarkar, K. 2017. Flora and Fauna of Bishnupur Beel and Berhampore. International Journal of Agriculture, Environment and Biotechnology. 10(5): 539-551.

Chattoraj, Sayantani, Dey, Santi Ranjan, Ambiya, Golam and Bhattacharya, Shilanjan. 2016. Vertebrate Biodiversity in and around Ahiran: An important Wetland in Murshidabad, West Bengal, India. Indian Journal of Biology (p-ISSN 23941391, e-ISSN 2455-8249) IJB, Vol.3 No.1 Jan-June 2016, pp. $57-66$.

De, Mitu, Medda, Suchismita and Dey, Santi Ranjan. 2018. Ecological Health of Wetland Ecosystem: An overview. International Journal of Experimental Research and Review, (ISSN- 24554855), Vol. 17: Dec issue, pp. 20-29.

De, Mitu, Panigrahi, Ashis Kumar, Roy, Anirban and Dey, Santi Ranjan. 2016. A comparative account of the impact of the urban development on plant and wetland dependent bird population along the two arms of an ox-bow lake, Motijheel in Murshidabad district. Indian Journal of Biology (p-ISSN 23941391, e-ISSN 2455-8249) IJB, Vol.3 No.1 Jan-June 2016, pp. $41-47$. course of time. Correlation with the aquatic vegetation which provide nesting sites for the birds and avian diversity would be another potential area of research.

\section{Acknowledgments:}

The author would also take this opportunity to thank Mr. Ratul Singha of Berhampore, Murshidabad who accompanied the author during the bird counts. This work has been carried out with the financial assistance of a Research Project of the West Bengal Biodiversity Board (WBBB) to the author as principal investigator.

\section{Conflicts of Interest:}

The author declare that the research was conducted in the absence of any commercial or economic associations that could be construed as a potential conflict of interest.

De, Mitu and Dey, Santi Ranjan. 2015. Aquaresources of Patan Wetland, Murshidabad : Floral and faunal diversity. Poster presentation in the National Seminar on 'Aquaresources: Care and Concerns' organized by the Social Environmental and Biological Association (SEBA) on $14^{\text {th }}$ February, 2015.

Dey, Santi Ranjan. 2019. Avifauna of Patan Wetland, Murshidabad, West Bengal,India. Int. J. Exp. Res. Rev., (ISSN- 2455-4855), Vol. 18: pp. 1521.

Ghosh, Prasenjit \& Goel, Sudha. 2014. Physical and chemical characterization of pond ash. International Journal of Environmental Research and Development. 4. 129-134.

IUCN. 2017. The IUCN red list of threatened species. Version 2017-3. www.iucnredlist.org

Jala, S. and D. Goyal. 2006. Flyash as a soil ameliorant for improving crop production-a review. Bioresource technology. 97(9): 1136-1147.

Koparde, Pankaj \& Patil, Purushottam \& Sawarkar, Prafull \& Shindikar, Mahesh. 2012. Birds from Ashes: Birdlife at Fly ash Ponds of Nashik, Maharashtra, India. Sarovar Saurabh. 8. 2-5.

Kumar, A., Sati, J. P., Tak, P. C. and Alfred, J. R. B. 2005. Handbook on Indian Wetland Birds and their Conservation: ISBN 81-8171-058-4, Zoological Survey of India. $468 \mathrm{pp}$

Kumar, P., Gupta, S.K. 2013. Status of wetland birds of Chhilchhila Wildlife Sanctuary, Haryana, India, Journal of Threatened Taxa, 5(5): 39693976 . 
Kumar, P., and Gupta, S. 2009. Diversity and Abundance of Wetland Birds around Kurukshetra, India. Our Nature, 7(1), 212-217.

Lee and Rotenberry. 2005. Relationships between bird species and tree species assemblages in Forested habitats of eastern North America. Journal of Biogeography, 32, pp. 1139-1150

Maltby, E.R. 1986. Waterlogged Wealth: Why Waste the World's Wet Places? Earth Scan, London, UK, 132pp.

Maltby, E., Turner, R.E. 1983. Wetlands of the world. Geographical Magazine 55: 12-17.

Manakadan, Ranjit \& Pittie, Aasheesh. 2001. Standardised common and scientific names of the birds of the Indian subcontinent. Buceros. 6. 1-37.

Mistry, J. and Mukherjee, S. 2015. Status and threats of water birds of Ahiran. International Journal of Plant, Animal and Environmental Science. 5(1): 59-64.

Mitsch, W.J., Gosselink. 2000. Wetlands. John Wiley \& Sons Inc, United States of America, 356pp.

Prasad, S.N., Ramachandra, T.V., Ahalya, N., Sengupta, T., Kumar, A., Tiwari, A.K., Vijayan, V.S., Vijayan, L. 2002. Conservation of wetlands of IndiaA review. Tropical Ecology 43(1): 173-186.

Ramsar. 2007. Wise use of wetlands: A conceptual framework for the wise use of wetlands. Ramsar handbooks for the wise use of wetlands, vol. 1, ( $3^{\text {rd }}$ edition), Ramsar Convention Secretariat, Gland, Switzerland.
Reinkensmeyer, D., Miller, R. F., Anthony, R. G., Mara, V. E. 2007. Avian community structure along a Mountain big Sagebrush succession Gradient. Journal of Wildlife Management, 71, pp. 1057-1066

Stewart, R.E. 2001. Technical Aspects of Wetlands - Wetlands as Bird Habitat. National Water Summary on Wetland Resources. United States Geological Survey, 86pp.

Suresh, I.V., Padmakar, C., Padmakaran, P., Murthy, M.V.R.L., Raju, C.B., Yadava, R.N. and Venkata Rao, K. 1998. "Effect of pond ash on ground water quality: a case study", Environmental Management and Health, Vol. 9 No. 5, pp. 200-208.

Urfi, A.J., Sen, M., Megnathan, T. 2005. Counting birds in India: methodologies and trend. Current Science 89(12): 1997-2003.

Weller, M.W. 1999. Wetland Birds Habitat Resources and Conservation Implications. Press syndicate of the University of Cambridge, United Kingdom, 137pp.

Zedler and Kercher. 2005. Wetland resources: Status, trends, ecosystem services, and restorability. Annual Review of Environment and Resources, 30, pp. 39-74. 